\title{
Flavobacterium ponti sp. nov., isolated from seawater
}

Correspondence
Wonyong Kim
kimwy@cau.ac.kr

\author{
Jung-Hoon Yoon, ${ }^{1}$ Sooyeon Park, ${ }^{1}$ So-Jung Kang, ${ }^{1}$ Soo-Jin Oh, ${ }^{1,2}$ \\ Soon Chul Myung ${ }^{3}$ and Wonyong $\mathrm{Kim}^{2}$
}

\author{
${ }^{1}$ Korea Research Institute of Bioscience and Biotechnology (KRIBB), PO Box 115, Yusong, Taejon, \\ Republic of Korea \\ ${ }^{2}$ Department of Microbiology and Research Institute for Translational System Biomics, Chung-Ang \\ University College of Medicine, Seoul 156-756, Republic of Korea \\ ${ }^{3}$ Department of Urology and Research Institute for Translational System Biomics, Chung-Ang \\ University College of Medicine, Seoul 156-756, Republic of Korea
}

The genus Flavobacterium was created by Bergey et al. (1923). Phylogenetically, it constitutes a distinct evolutionary lineage within the family Flavobacteriaceae of the phylum 'Bacteroidetes' (Bernardet \& Nakagawa, 2006). Recently, continuous descriptions of novel species, e.g. eight species in 2007, four species in 2008 and eight species in 2009, have increased considerably the number of species belonging to the genus Flavobacterium. At the time of writing, the genus Flavobacterium comprised at least 62 species with validly published names (Euzéby, 2009; http:// www.bacterio.cict.fr). In this study, a bacterial strain, GSW$\mathrm{R} 14^{\mathrm{T}}$, which was isolated from seawater of Geoje Island in the South Sea, Korea, is described. Comparative 16S rRNA gene sequence analysis indicated that strain GSW-R $14^{\mathrm{T}}$ is a member of the genus Flavobacterium. The aim of the present work was to determine the exact taxonomic position of strain GSW-R $14^{\mathrm{T}}$ by using a polyphasic characterization that included the determination of phenotypic properties, a

The GenBank/EMBL/DDBJ accession number for the 16S rRNA gene sequence of strain GSW-R14 $4^{\top}$ is G0370387. detailed phylogenetic investigation based on 16S rRNA gene sequences and genetic analysis.

The standard dilution plating technique was used for the isolation of bacterial strains from seawater samples. Strain GSW-R14 ${ }^{\mathrm{T}}$ was isolated on marine agar 2216 (MA; Difco) at $25{ }^{\circ} \mathrm{C}$ and cultivated routinely under these isolation conditions. For short-term preservation, serial transfer from agar slants to an appropriate medium was used and the agar slants were stored at $4{ }^{\circ} \mathrm{C}$. For long-term preservation, the strain was preserved at $-80{ }^{\circ} \mathrm{C}$ in a deep freeze or in liquid nitrogen as a suspension in $20 \%(\mathrm{w} / \mathrm{v})$ glycerol. Flavobacterium gelidilacus LMG $21477^{\mathrm{T}}$ was used as a reference strain for DNA-DNA hybridization, phenotypic characterization, and isoprenoid quinone and fatty acid analyses. Cell morphology was examined by using light microscopy (E600; Nikon) and transmission electron microscopy (CM-20; Philips). The presence of flagella was assessed by using transmission electron microscopy of cells from an exponentially growing culture. For this purpose, cells were negatively stained with $1 \%(\mathrm{w} / \mathrm{v})$ phosphotungstic acid and the grids were examined after being 
air-dried. Gliding motility was investigated as described by Bowman (2000). The Gram reaction was determined using the bioMérieux Gram staining kit according to the manufacturer's instructions. Growth at 4, 15, 20, 25, 30, 35,37 and $40{ }^{\circ} \mathrm{C}$ was measured on MA. The $\mathrm{pH}$ range for growth was investigated in marine broth 2216 (MB; Difco) adjusted to $\mathrm{pH} 4.5-10.0$ in increments of $0.5 \mathrm{pH}$ units by using sodium acetate/acetic acid and $\mathrm{Na}_{2} \mathrm{CO}_{3}$ buffers. Growth in the absence of $\mathrm{NaCl}$ and in the presence of 0.5 , $1.0,2.0$ and $3.0 \%(\mathrm{w} / \mathrm{v}) \mathrm{NaCl}$ was investigated in trypticase soy broth prepared according to the formula of the Difco medium except that $\mathrm{NaCl}$ was excluded and that $0.45 \%$ (w/v) $\mathrm{MgCl}_{2} \cdot 6 \mathrm{H}_{2} \mathrm{O}$ or $0.06 \%$ (w/v) $\mathrm{KCl}$ was added. Growth in the presence of final concentrations of $\mathrm{NaCl}$ of $2.0-8.0 \%(\mathrm{w} / \mathrm{v})$ (in increments of $1.0 \%$ ) was investigated in MB. Growth under anaerobic conditions was investigated in a Forma anaerobic chamber on MA and on MA supplemented with $0.1 \%(\mathrm{w} / \mathrm{v})$ potassium nitrate, both of which had been prepared anaerobically under a nitrogen atmosphere. Catalase and oxidase activities were determined as described by Cowan \& Steel (1965). Hydrolysis of casein, hypoxanthine, starch, xanthine, tyrosine, and Tweens 20,40, 60 and 80 was performed on MA using the substrate concentrations described previously (Cowan \& Steel, 1965). Nitrate reduction and hydrolysis of aesculin, gelatin and urea were performed as described by Lányí (1987) with the modification that artificial seawater $(23.6 \mathrm{~g}$ $\mathrm{NaCl}, 0.64 \mathrm{~g} \mathrm{KCl}, 4.53 \mathrm{~g} \mathrm{MgCl}_{2} .6 \mathrm{H}_{2} \mathrm{O}, 5.94 \mathrm{~g} \mathrm{MgSO}_{4}$. $7 \mathrm{H}_{2} \mathrm{O}$ and $1.3 \mathrm{~g} \mathrm{CaCl}_{2} \cdot 2 \mathrm{H}_{2} \mathrm{O}$ per litre of distilled water; Bruns et al., 2001) was used for preparation of media. Degradation of CM-cellulose (Sigma) was investigated on MA containing $0.5 \%$ CM-cellulose and detected according to the method of Teather \& Wood (1982). DNase activity was examined by using DNase test agar with methyl green (Difco) with the modification that artificial seawater was used for preparation of the medium. The presence of flexirubin-type pigments was investigated as described by Reichenbach (1992). Acid production from carbohydrates was assessed as described by Leifson (1963). Susceptibility to antibiotics was tested on MA plates using antibiotic discs (BBL) containing the following: ampicillin $(10 \mu \mathrm{g})$, carbenicillin $(100 \mu \mathrm{g})$, cephalothin $(30 \mu \mathrm{g})$, chloramphenicol $(100 \mu \mathrm{g})$, gentamicin $(30 \mu \mathrm{g})$, kanamycin $(30 \mu \mathrm{g})$, lincomycin $(15 \mu \mathrm{g})$, neomycin $(30 \mu \mathrm{g})$, novobiocin $(5 \mu \mathrm{g})$, oleandomycin $(15 \mu \mathrm{g})$, penicillin $\mathrm{G}(20 \mathrm{U})$, polymyxin $\mathrm{B}$ $(100 \mathrm{U})$, streptomycin $(50 \mu \mathrm{g})$ and tetracycline $(30 \mu \mathrm{g})$. Enzyme activities and additional biochemical tests were performed by using the API ZYM and API 20E systems (bioMérieux) incubated at $25{ }^{\circ} \mathrm{C}$ according to the instructions of the manufacturer. Morphological, cultural, physiological and biochemical properties of strain GSW-R14 ${ }^{\mathrm{T}}$ are given in the species description and in Table 1. Strain GSW$\mathrm{R} 14^{\mathrm{T}}$ grew anaerobically on MA and on MA supplemented with nitrate. Some species of the genus Flavobacterium have been known to grow anaerobically through the reduction of nitrate, including Flavobacterium denitrificans, which has been reported to use nitrate as an electron acceptor (Horn et al., 2005; Bernardet \& Bowman, 2006).
Table 1. Differential phenotypic characteristics of strain GSW-R14 $4^{\top}$ and Flavobacterium gelidilacus LMG $21477^{\top}$

Strains: 1, Flavobacterium ponti sp. nov. GSW-R14 ${ }^{\mathrm{T}} ; 2$, F. gelidilacus LMG $21477^{\mathrm{T}}$. Data are from this study except where marked. + , Positive reaction; -, negative reaction; $\mathrm{W}$, weakly positive reaction. Both strains are positive for: growth at $30{ }^{\circ} \mathrm{C}$; hydrolysis of casein, gelatin, starch, and Tweens 20, 40, 60 and 80; acid production from D-mannose and maltose; catalase, oxidase, alkaline phosphatase, esterase (C4), esterase lipase (C8), leucine arylamidase, valine arylamidase (weak for GSW-R14 ${ }^{\mathrm{T}}$ ), cystine arylamidase (weak for both strains) and $\alpha$-glucosidase (weak for LMG $21477^{\mathrm{T}}$ ) activities; and susceptibility to chloramphenicol, lincomycin and oleandomycin. Both strains are negative for: Gram staining, spore formation, gliding motility, production of flexirubin-type pigments and nitrate reduction [data for these characteristics for F. gelidilacus LMG $21477^{\mathrm{T}}$ are from Van Trappen et al. (2003)]; hydrolysis of agar, aesculin, hypoxanthine and xanthine; production of acetoin, $\mathrm{H}_{2} \mathrm{~S}$ and indole; acid production from L-arabinose, cellobiose, D-galactose, D-fructose, myo-inositol, lactose, D-mannitol, melezitose, melibiose, raffinose, L-rhamnose, D-ribose, D-sorbitol, sucrose, trehalose and D-xylose; urease, arginine dihydrolase, lysine decarboxylase, ornithine decarboxylase, tryptophan deaminase, lipase (C14), $\alpha$-chymotrypsin, $\alpha$-galactosidase, $\beta$-galactosidase, $\beta$-glucuronidase, $\beta$-glucosidase, $N$-acetyl- $\beta$-glucosaminidase, $\alpha$-mannosidase and $\alpha$-fucosidase activities; and susceptibility to ampicillin, cephalothin, gentamicin, kanamycin, neomycin, penicillin $\mathrm{G}$ and polymyxin $\mathrm{B}$.

\begin{tabular}{|lcc|}
\hline Characteristic & $\mathbf{1}$ & $\mathbf{2}$ \\
\hline Growth at $35{ }^{\circ} \mathrm{C}$ & + & - \\
Anaerobic growth with nitrate & + & $-{ }^{*}$ \\
Hydrolysis of L-tyrosine & + & - \\
Enzyme activity (API ZYM): & & \\
$\quad$ Trypsin & - & W \\
Acid phosphatase & - & W \\
Naphthol-AS-BI-phosphohydrolase & - & W \\
Acid production from D-glucose & + & - \\
Susceptibility to: & & \\
Carbenicillin & + & W \\
Novobiocin & - & + \\
Streptomycin & + & W \\
Tetracycline & - & + \\
\end{tabular}

${ }^{*}$ Data from Van Trappen et al. (2003).

Cell biomass for DNA extraction and isoprenoid quinone analysis was obtained from cultures grown for 3 days in $\mathrm{MB}$ at $25^{\circ} \mathrm{C}$. Chromosomal DNA was extracted and purified according to the method described by Yoon et al. (1996), with the modification that RNase T1 was used in combination with RNase A to minimize contamination by RNA. The 16S rRNA gene amplification was performed using two universal primers as described previously (Yoon et al., 1998) and PCR products were purified by using a QIAquick PCR purification kit (Qiagen). Sequencing of the amplified 16S rRNA gene and phylogenetic analysis were performed as described by Yoon et al. (2003). The 


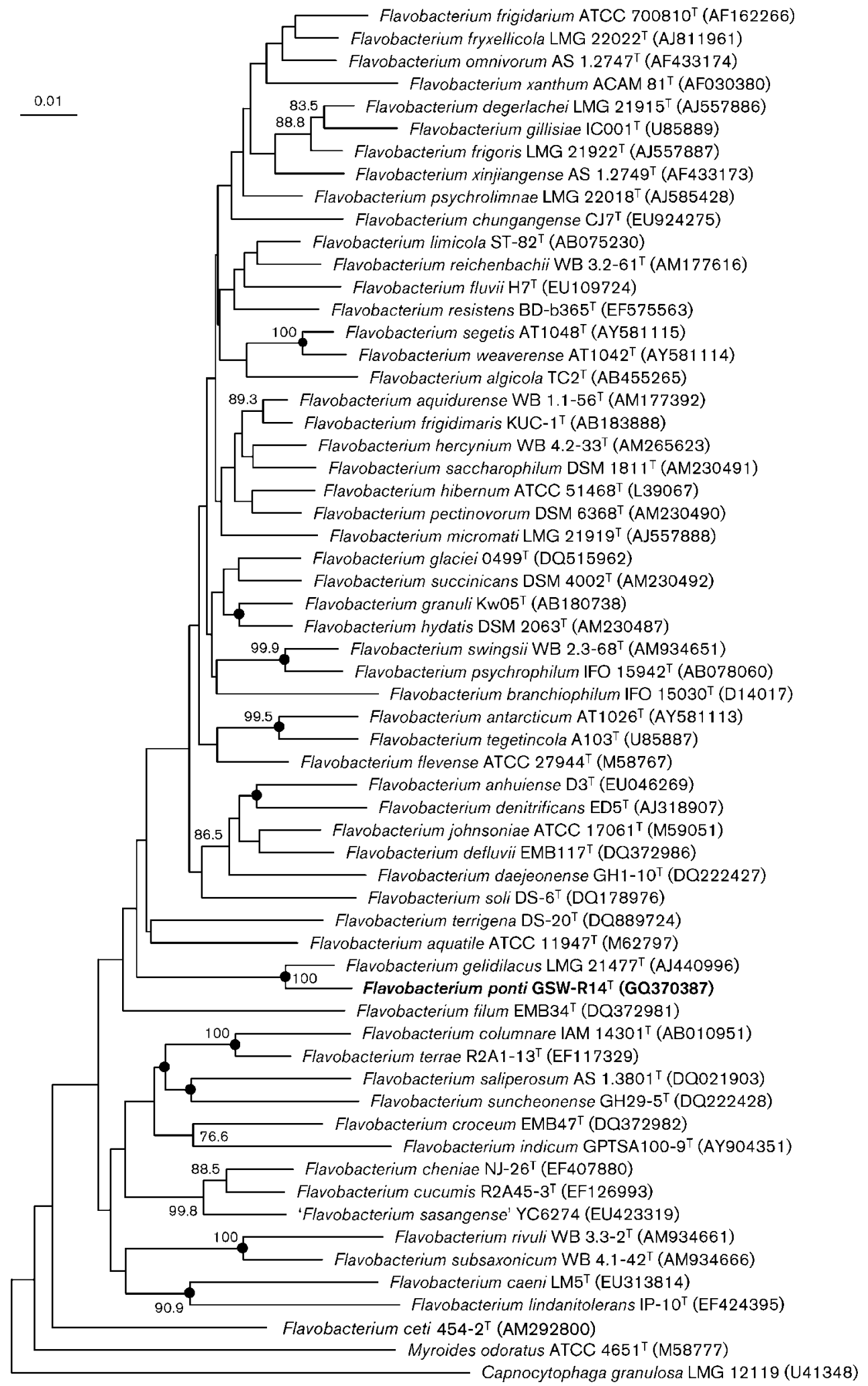

Fig. 1. Neighbour-joining tree based on 16S rRNA gene sequences showing the phylogenetic position of Flavobacterium ponti GSW-R14 ${ }^{T}$ and other related taxa. Bootstrap values (expressed as percentages of 1000 replications) $>70 \%$ are shown at branching points. Filled circles indicate that the corresponding nodes were also recovered in trees generated with the maximum-likelihood and maximum-parsimony algorithms. Capnocytophaga granulosa LMG 12119 (GenBank accession no. U41348) was used as an outgroup. Bar, 0.01 substitutions per nucleotide position. 
almost-complete 16S rRNA gene sequence of strain GSW$\mathrm{R} 14^{\mathrm{T}}$ determined in this study comprised $1438 \mathrm{bp}$, representing approximately $96 \%$ of the Escherichia coli $16 \mathrm{~S}$ rRNA gene sequence. In the phylogenetic tree reconstructed using the neighbour-joining algorithm, strain GSW-R $14^{\mathrm{T}}$ fell within the clade comprising species of the genus Flavobacterium, joining F. gelidilacus LMG $21477^{\mathrm{T}}$ with a bootstrap confidence value of $100 \%$ (Fig. 1). The relationship between strain GSW-R $14^{\mathrm{T}}$ and F. gelidilacus LMG $21477^{\mathrm{T}}$ was also maintained in phylogenetic trees reconstructed using the maximum-likelihood and maximum-parsimony algorithms (Fig. 1). Strain GSW-R14 ${ }^{\mathrm{T}}$ exhibited $97.6 \% 16 \mathrm{~S}$ rRNA gene sequence similarity to $F$. gelidilacus LMG $21477^{\mathrm{T}}$ and $91.2-95.2 \%$ to the type strains of the other species of the genus Flavobacterium.

Isoprenoid quinones were analysed as described by Komagata \& Suzuki (1987) using reversed-phase HPLC and a YMC ODS-A $(250 \times 4.6 \mathrm{~mm})$ column. The predominant isoprenoid quinone detected in strain GSW-R $14^{\mathrm{T}}$ was MK-6, which is in line with all members of the family Flavobacteriaceae (Bernardet \& Nakagawa, 2006). For cellular fatty acid analysis, cell masses of strain GSW$\mathrm{R} 14^{\mathrm{T}}$ and F. gelidilacus LMG $21477^{\mathrm{T}}$ were harvested from MA plates after cultivation for 3 days at $25^{\circ} \mathrm{C}$. Fatty acids were extracted and fatty acid methyl esters were prepared according to the standard protocol of the MIDI/Hewlett Packard Microbial Identification System (Sasser, 1990). The cellular fatty acid profiles of strain GSW-R $14^{\mathrm{T}}$ and F. gelidilacus LMG $21477^{\mathrm{T}}$ analysed in this study are compared in Table 2 . The fatty acid profiles of the two strains were similar, although there were differences in the proportions of some fatty acids (Table 2 ). The DNA G +C content was determined by the method of Tamaoka \& Komagata (1984) with the modification that DNA was hydrolysed using nuclease P1 (Sigma) and the resultant nucleotides were analysed by reversed-phase HPLC. The DNA G + C content of strain GSW-R14 ${ }^{\mathrm{T}}$ was $31.4 \mathrm{~mol} \%$, which is in the range of values determined for species of the genus Flavobacterium (Bernardet \& Bowman, 2006) and similar to that (30.0-30.4 mol\%) reported for F. gelidilacus (Van Trappen et al., 2003).

DNA-DNA hybridization was performed fluorometrically by the method of Ezaki et al. (1989) using photobiotinlabelled DNA probes and microdilution wells. Hybridization was performed at $45{ }^{\circ} \mathrm{C}$ with five replications for each sample. The highest and lowest values obtained for each sample were excluded and the means of the remaining three values were quoted as DNA-DNA relatedness values. The mean DNA-DNA relatedness value between strain GSW-R14 ${ }^{\mathrm{T}}$ and F. gelidilacus LMG $21477^{\mathrm{T}}$ was $31 \%$, indicating that they belong to two different species (Wayne et al., 1987). Strain GSW-R14 ${ }^{\mathrm{T}}$ can also be differentiated from F. gelidilacus LMG $21477^{\mathrm{T}}$ by differences in several phenotypic characteristics, activity of several enzymes and susceptibility to several antibiotics (Table 1). Accordingly, the phylogenetic and genetic distinctiveness and differential phenotypic properties of strain GSW-R14 ${ }^{\mathrm{T}}$ warrant its description as a representative of a novel species of the genus Flavobacterium, for which the name Flavobacterium ponti sp. nov. is proposed.

\section{Description of Flavobacterium ponti sp. nov.}

Flavobacterium ponti [pon'ti. L. gen. n. ponti (poet. for maris) of the sea, referring to the place that the type strain was isolated].

Cells are Gram-stain-negative, non-flagellated, non-gliding, non-endospore-forming and rod-shaped, $0.3-0.8 \mu \mathrm{m}$ in diameter and $0.8-5.0 \mu \mathrm{m}$ in length. Colonies on MA are circular with regular edges, convex, glistening, smooth, yellow in colour and $0.5-1.0 \mathrm{~mm}$ in diameter after incubation for 3 days at $25{ }^{\circ} \mathrm{C}$. Flexirubin-type pigments are not produced. Anaerobic growth occurs on MA and on MA supplemented with nitrate. Optimal growth temperature is $25{ }^{\circ} \mathrm{C}$; growth occurs at 10 and $35{ }^{\circ} \mathrm{C}$, but not at 4 or $37^{\circ} \mathrm{C}$. Optimal $\mathrm{pH}$ for growth is between 7.0 and 8.0; growth occurs at $\mathrm{pH} 5.0$, but not at $\mathrm{pH} 4.5$. Growth occurs in the presence of $0-6 \%(\mathrm{w} / \mathrm{v}) \mathrm{NaCl}$, with optimum growth in approximately $2.0 \%(\mathrm{w} / \mathrm{v}) \mathrm{NaCl} . \mathrm{Mg}^{2+}$ ions are

Table 2. Cellular fatty acid composition (\%) of strain GSW-R14 ${ }^{\top}$ and Flavobacterium gelidilacus LMG $21477^{\top}$

Strains: 1, Flavobacterium ponti sp. nov. GSW-R14 ${ }^{\mathrm{T}} ; 2$, F. gelidilacus LMG $21477^{\mathrm{T}}$. All data are from this study. Fatty acids representing $<1.0 \%$ in both strains were omitted. tr, Trace $(<1.0 \%)$.

\begin{tabular}{|c|c|c|}
\hline Fatty acid & 1 & 2 \\
\hline \multicolumn{3}{|l|}{ Straight-chain: } \\
\hline $\mathrm{C}_{15: 0}$ & 12.9 & 13.2 \\
\hline \multicolumn{3}{|l|}{ Unsaturated: } \\
\hline $\mathrm{C}_{15: 1} \omega 6 c$ & 5.4 & 8.7 \\
\hline $\mathrm{C}_{17: 1} \omega 6 c$ & 2.3 & 5.6 \\
\hline \multicolumn{3}{|l|}{ Branched: } \\
\hline iso- $\mathrm{C}_{13: 0}$ & 1.1 & $\operatorname{tr}$ \\
\hline iso- $\mathrm{C}_{14: 0}$ & 1.0 & 2.6 \\
\hline iso- $\mathrm{C}_{15: 0}$ & 18.5 & 9.4 \\
\hline iso- $\mathrm{C}_{15: 1}$ & 12.2 & 7.2 \\
\hline anteiso- $\mathrm{C}_{15: 0}$ & 2.1 & 4.5 \\
\hline iso- $\mathrm{C}_{16: 0}$ & 1.8 & 6.3 \\
\hline iso- $\mathrm{C}_{16: 1}$ & $\operatorname{tr}$ & 3.4 \\
\hline iso- $\mathrm{C}_{17: 1} \omega 9 c$ & 2.8 & 1.1 \\
\hline \multicolumn{3}{|l|}{ Hydroxy: } \\
\hline $\mathrm{C}_{15: 0} 3-\mathrm{OH}$ & 1.6 & 2.2 \\
\hline iso- $\mathrm{C}_{15: 0} 3-\mathrm{OH}$ & 8.3 & 5.8 \\
\hline $\mathrm{C}_{16: 0} 3-\mathrm{OH}$ & $\operatorname{tr}$ & 1.1 \\
\hline iso- $\mathrm{C}_{16: 0} 3-\mathrm{OH}$ & 2.7 & 11.5 \\
\hline $\mathrm{C}_{17: 0} 3-\mathrm{OH}$ & $\operatorname{tr}$ & 1.1 \\
\hline iso- $\mathrm{C}_{17: 0} 3-\mathrm{OH}$ & 13.4 & 7.3 \\
\hline Summed feature $3^{\star}$ & 5.0 & 2.2 \\
\hline
\end{tabular}

* Summed features represent groups of two or three fatty acids that cannot be separated by GLC with the MIDI system. Summed feature 3 contained $\mathrm{C}_{16: 1} \omega 7 c$ and/or iso- $\mathrm{C}_{15: 0} 2-\mathrm{OH}$. 
required for growth. Catalase- and oxidase-positive. Nitrate is not reduced to nitrite. Casein, DNA, gelatin, starch, tyrosine, and Tweens 20, 40, 60 and 80 are hydrolysed, but aesculin, agar, CM-cellulose, hypoxanthine, urea and xanthine are not. Acetoin, $\mathrm{H}_{2} \mathrm{~S}$ and indole are not produced. The predominant menaquinone is MK-6. The major cellular fatty acids $(>10 \%$ of the total fatty acids) are iso- $\mathrm{C}_{15: 0}$, iso- $\mathrm{C}_{17: 0} 3-\mathrm{OH}, \mathrm{C}_{15: 0}$ and iso$\mathrm{C}_{15: 1}$. Additional phenotypic characteristics are given in Table 1.

The type strain is GSW-R $14^{\mathrm{T}}\left(=\mathrm{KCTC} 22802^{\mathrm{T}}=\mathrm{CCUG}\right.$ $58402^{\mathrm{T}}$ ), isolated from seawater of Geoje Island in the South Sea, Korea. The DNA G $+\mathrm{C}$ content of the type strain is $31.4 \mathrm{~mol} \%$.

\section{Acknowledgements}

This study was supported by a grant of the Korea Healthcare Technology R\&D Project (grant A085138) from the Ministry for Health, Welfare \& Family Affairs of Republic of Korea.

\section{References}

Bergey, D. H., Harrison, F. C., Breed, R. S., Hammer, B. W. \& Huntoon, F. M. (editors) (1923). Bergey's Manual of Determinative Bacteriology. Baltimore: Williams \& Wilkins.

Bernardet, J.-F. \& Bowman, J. P. (2006). The genus Flavobacterium. In The Prokaryotes: a Handbook on the Biology of Bacteria, 3rd edn, vol. 7, pp. 481-531. Edited by M. Dworkin, S. Falkow, E. Rosenberg, K.-H. Schleifer \& E. Stackebrandt. New York: Springer.

Bernardet, J.-F. \& Nakagawa, Y. (2006). An introduction to the family Flavobacteriaceae. In The Prokaryotes: a Handbook on the Biology of Bacteria, 3rd edn, vol. 7, pp. 455-480. Edited by M. Dworkin, S. Falkow, E. Rosenberg, K.-H. Schleifer \& E. Stackebrandt. New York: Springer.

Bowman, J. P. (2000). Description of Cellulophaga algicola sp. nov., isolated from the surfaces of Antarctic algae, and reclassification of Cytophaga uliginosa (ZoBell and Upham 1944) Reichenbach 1989 as Cellulophaga uliginosa comb. nov. Int J Syst Evol Microbiol 50, 18611868.

Bruns, A., Rohde, M. \& Berthe-Corti, L. (2001). Muricauda ruestringensis gen. nov., sp. nov., a facultatively anaerobic, appendaged bacterium from German North Sea intertidal sediment. Int J Syst Evol Microbiol 51, 1997-2006.

Cowan, S. T. \& Steel, K. J. (1965). Manual for the Identification of Medical Bacteria. London: Cambridge University Press.
Euzéby, J. P. (2009). List of prokaryotic names with standing in nomenclature. [Last full update 6 February 2009]. http://www. bacterio.net

Ezaki, T., Hashimoto, Y. \& Yabuuchi, E. (1989). Fluorometric deoxyribonucleic acid-deoxyribonucleic acid hybridization in microdilution wells as an alternative to membrane filter hybridization in which radioisotopes are used to determine genetic relatedness among bacterial strains. Int J Syst Bacteriol 39, 224-229.

Horn, M. A., Ihssen, J., Matthies, C., Schramm, A., Acker, G. \& Drake, H. L. (2005). Dechloromonas denitrificans sp. nov., Flavobacterium denitrificans sp. nov., Paenibacillus anaericanus sp. nov. and Paenibacillus terrae strain $\mathrm{MH} 72, \mathrm{~N}_{2} \mathrm{O}$-producing bacteria isolated from the gut of the earthworm Aporrectodea caliginosa. Int J Syst Evol Microbiol 55, 1255-1265.

Komagata, K. \& Suzuki, K. (1987). Lipid and cell-wall analysis in bacterial systematics. Methods Microbiol 19, 161-207.

Lányí, B. (1987). Classical and rapid identification methods for medically important bacteria. Methods Microbiol 19, 1-67.

Leifson, E. (1963). Determination of carbohydrate metabolism of marine bacteria. J Bacteriol 85, 1183-1184.

Reichenbach, H. (1992). The order Cytophagales. In The Prokaryotes, 2nd edn, vol. 4, pp. 3631-3675. Edited by A. Balows, H. G. Trüper, M. Dworkin, W. Harder \& K. H. Schleifer. New York: Springer.

Sasser, M (1990). Identification of bacteria by gas chromatography of cellular fatty acids, MIDI Technical Note 101. Newark, DE: MIDI Inc.

Tamaoka, J. \& Komagata, K. (1984). Determination of DNA base composition by reversed-phase high-performance liquid chromatography. FEMS Microbiol Lett 25, 125-128.

Teather, R. M. \& Wood, P. J. (1982). Use of Congo red-polysaccharide interactions in enumeration and characterization of cellulolytic bacteria from the bovine rumen. Appl Environ Microbiol 43, 777-780.

Van Trappen, S., Mergaert, J. \& Swings, J. (2003). Flavobacterium gelidilacus sp. nov., isolated from microbial mats in Antarctic lakes. Int J Syst Evol Microbiol 53, 1241-1245.

Wayne, L. G., Brenner, D. J., Colwell, R. R., Grimont, P. A. D., Kandler, O., Krichevsky, M. I., Moore, L. H., Moore, W. E. C., Murray, R. G. E. \& other authors (1987). International Committee on Systematic Bacteriology. Report of the ad hoc committee on reconciliation of approaches to bacterial systematics. Int J Syst Bacteriol 37, 463-464.

Yoon, J.-H., Kim, H., Kim, S.-B., Kim, H.-J., Kim, W. Y., Lee, S. T., Goodfellow, M. \& Park, Y.-H. (1996). Identification of Saccharomonospora strains by the use of genomic DNA fragments and rRNA gene probes. Int J Syst Bacteriol 46, 502-505.

Yoon, J.-H., Lee, S. T. \& Park, Y.-H. (1998). Inter- and intraspecific phylogenetic analysis of the genus Nocardioides and related taxa based on 16S rDNA sequences. Int J Syst Bacteriol 48, 187-194.

Yoon, J.-H., Kang, K. H. \& Park, Y.-H. (2003). Psychrobacter jeotgali sp. nov., isolated from jeotgal, a traditional Korean fermented seafood. Int J Syst Evol Microbiol 53, 449-454. 